
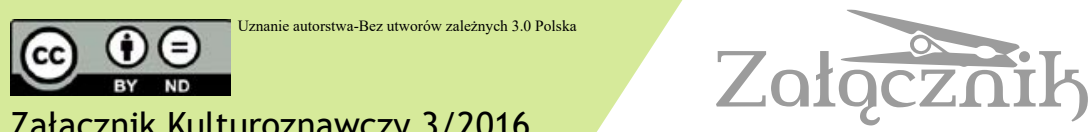

Załącznik Kulturoznawczy 3/2016

TEMAT NUMERU: KICZ NASZ WSPÓLCZESNY

\title{
KICZ Z IMPORTU? WPROWADZENIE DO ODBIORU I OCENY JAPOŃSKIEJ ANIMACJI
}

HELENA JADWISZCZOK-MOLENCKA,

Wydział Filologiczny Uniwersytetu Śląskiego w Katowicach Department of Philology, University of Silesia in Katowice JACEK MOLENCKI

\section{ZJAWISKO KICZU, KULTURA MASOWA I ANIME}

Zjawisko kiczu w powszechnym ujęciu łączone jest z lichością, słabą jakością materiału, tandetą, brakiem wartości artystycznych. Jako element kultury masowej zostało ono szczegółowo opisane i przeanalizowane z perspektywy socjologicznej, psychologicznej, kulturoznawczej i historycznej. Kicz nie jest jednak zjawiskiem specyficznie XX-wiecznym czy postmodernistycznym, wiązać go bowiem można ze znacznie wcześniejszą i szerszą tendencją do społecznej akceptacji dla wytworów w umiarkowanie złym guście. Marek Hendrykowski uważa, że pod kategorię kiczu podchodzą już realizacje Giotta di Bodone, Rafaela Santi, romantyczny patos przedstawień heroicznych, opery Ryszarda Wagnera czy też niektóre dzieła Adama Mickiewicza i innych znanych pisarzy1. Abraham Moles nazywa kicz „sztuką szczęścia” i rajem dla mało wymagających ${ }^{2}$.

Samo pojęcie kiczu spopularyzowali w latach 20. XX wieku Theodor Adorno, Clement Greenberg i Hermann Broch, dla których był on rodzajem fałszywej świadomości ${ }^{3}$. Zdaniem Brocha, kicz to nie tyle kwestia estetyczna, co etyczna. Austriacki pisarz nazywał go „złem w systemie wartości sztuki", twierdząc przy tym, iż celem kiczu jest świadome odwrócenie

${ }^{1}$ M. Hendrykowski, Kłopoty z kiczem filmowym, [w:] Niedyskretny urok kiczu. Problemy filmowej kultury popularnej, red. G. Stachówna, Kraków 1997, s. 15-16.

2 A. Moles, Kicz, czyli sztuka szczęścia. Studium o psychologii kiczu, tłum. A. Szczepańska, E. Wende, Warszawa 1978.

3 Th. Adorno, Teoria estetyczna, tłum. K. Krzemieniowa, Warszawa 1994. 
hierarchii wartości, w ramach którego etyczna nikczemność prowadzi do Kantowskiego zła 4 . Podobnie kicz definiował Andrzej Banach, który widział w nim zagrożenie dla kultury i sztuki przezeń charakteryzowanej5.

Zdecydowanie mniej radykalne stanowisko przyjął wspomniany już Marek Hendrykowski, uznający kicz za tekst kultury, który winien być analizowany z perspektywy semiotycznej ${ }^{6}$. Abraham Moles wskazał natomiast na pięć zasad rządzących kiczem, do których zaliczył: niedostosowanie (przekroczenie zasady funkcjonalności w przedmiocie kiczowatym), kumulację (nagromadzenie w jednym przedmiocie różnych funkcji), synestezję (oddziaływanie na wiele zmysłów naraz), przeciętność (kicz znajduje się w pół drogi między tym, co akceptowane, a tym, co pociąga nowością) oraz komfort (unikanie wszystkiego, co trudne i niewygodne). Moles dowodził, iż kicz jest niezbędny dla funkcjonowania społeczeństwa, gdyż odzwierciedla wszystko to, czego nie odnajduje ono w sztuce?

Należy także wskazać, iż rehabilitacja kiczu nadeszła stosunkowo szybko w związku z modą na kamp w latach 60. XX wieku. Susan Sontag poprzez owo określenie rozumiała celowe przerysowanie, ironię, stosowanie estetyki z wyboru akanonicznej. I choć, podobnie jak w przypadku kiczu, proweniencję tego zjawiska można odnaleźć w wiekach minionych, to właśnie kamp stał się środkiem wyrazu dla wielu postmodernistycznych twórców ${ }^{8}$.

Kicz oraz kamp zyskały również miano głównych budulców kultury masowej. Produkty owej kultury uznawano, w zależności od kontekstu, za wytwory lepszej lub gorszej jakości, które jednak często wpływają na zniekształcenie ogólnej perspektywy odbioru danej kultury ${ }^{9}$. Niektórzy, jak Theodor Adorno, Maks Horkheimer lub Antonina Kłoskowska,

${ }^{4}$ H. Broch, Kilka uwag o kiczu, [w:] idem, Kilka uwag o kiczu i inne eseje, tłum. G. Borkowska, J. Garewicz, R. Turczyn, Warszawa 1998, s. 113-115.

5 Zob. A. Banach, O kiczu, Kraków 1968.

${ }_{6}$ M. Hendrykowski, op. cit.

7 A. Moles, op. cit.

8 S. Sontag, Notatki o kampie, tłum. M. Wertenstein, „Literatura na Świecie” 1979, nr 9.

9 A. Kłoskowska, Kultura masowa, Warszawa 2005, s. 94-104 i 320; J. Fiske, Zrozumieć kulturę popularną, tłum. K. Sawicka, Kraków 2010, s. 106-131; D. Strinati, Wprowadzenie do kultury popularnej, tłum. W.J. Burszta, Poznań 1998, s. 15-18. 
reprezentowali wobec kultury masowej stanowisko krytyczne, uznając ją za zjawisko negatywne. Inni zaś, na przykład Walter Benjamin, dostrzegali w niej również pozytywne aspekty. Noël Carroll w Filozofii sztuki masowej odnosi się do argumentów przemawiających zarówno za kulturą masową, jak i przeciw niej, wskazując przy tym na jej aspekty komercyjne. W jego ujęciu zapotrzebowanie społeczne na produkty kiczowate oraz kampowe nie jest czymś negatywnym, gdyż stanowi ono jedynie transpozycję ustalonych wzorców. Badacz porównuje także dyskursy obecne w produktach masowych i pochodzących z obszaru tak zwanej sztuki wysokiej, analizując warstwę treściową pod kątem zastosowanych rozwiązań i starając się nie wartościować owych produktów w zależności od ich proweniencji ${ }^{10}$.

W tym kontekście zaznaczyć należy, iż także kultura popularna rzadko badana jest pod kątem wzbogacania kompetencji kulturowych użytkowników, definiowana jest bowiem najczęściej jako zjawisko negatywne, prowadzące - poprzez dobór stosowanych środków - do stępienia wrażliwości odbiorców, propagowania biernego stosunku do życia i „zatracania samego siebie"11.

Dlatego też interesująca wydaje się koncepcja Dariusza Czai, który wskazuje, że kulturę popularną należałoby utożsamiać z kulturą ludową, czego uzasadnienie odnaleźć można chociażby w etymologii pierwszego terminu popularny oznacza wszak: rozpowszechniony, dostępny dla każdego. Czaja nie doszukuje się przy tym przejawów spłycania kulturowych treści w obrębie kultury popularnej, wyróżnia natomiast współistnienie w jej ramach różnych systemów kulturowych (archaicznych, mitologicznych, religijnych). Ponadto podkreśla konieczność badania kultury popularnej, gdyż, jak twierdzi, to ona właśnie najlepiej odzwierciedla współczesnośćc ${ }^{2}$.

Także sfera japońskiej popkultury, której anime stanowi część składową, była już tematem badań. Joanna Zaremba-Penk, nawiązując do terminu soft power autorstwa Josepha Nye'a, odniosła się do kwestii gospodarczych oraz eksportowania określonych towarów i idei poprzez popkulturę - w tym

${ }^{10}$ N. Carroll, Filozofia sztuki masowej, tłum. M. Przylipiak, Gdańsk 2011.

${ }_{11}$ Zob. M. Krajewski, Kultury kultury popularnej, Poznań 2003, s. 7-17 i 41; M. Golka, Socjologia kultury, Warszawa 2008, s. 146 i 156.

12 D. Czaja, Mitologie popularne. Szkice z antropologii współczesności, Kraków 1994, s. 10-12. 
wypadku popkulturę Japonii13 ${ }^{13}$. Anne Allison oraz Roland Kelts wskazali, iż atrakcyjność japońskich produktów popkulturowych jest niezaprzeczalna i zauważalna zwłaszcza w Stanach Zjednoczonych ${ }^{14}$. Podobnie Sharon Kinsell, która analizowała styl kawaii w kontekście eksportu na rynek zachodni produktów kultury popularnej ${ }^{15}$, oraz John E. Ingulsrund, zajmujący się w swoim projekcie badawczym zjawiskiem Japan cool ${ }^{16}$. Przywołać należy również badania Adrianny Wosińskiej, przeprowadzone zarówno na osobach interesujących się japońską kulturą popularną, jak i tych, dla których dziedzina ta jest obca. Ankiety autorki wykazały, iż oglądający anime i czytający mangi posiadają znacznie większą wiedzę na temat Japonii niż pozostali badani ${ }^{17}$. Wosińska powoływała się także na publikację Frederika L. Schodta, według którego zaadaptowanie mang na potrzeby rynku zachodniego wiąże się z licznymi przeszkodami, które związane są m.in. z koniecznością lustrzanego odbijania stron (w Japonii rewers jest awersem i odwrotnie) czy przeskalowania „dymków”, gdyż w oryginalnych trudno zmieścić przetłumaczony tekst. Problemem jest także tematyka, która w opinii Schodta - zrozumiała jest jedynie dla osób zaznajomionych z japońską kulturą ${ }^{18}$.

W temacie prowadzenia badań nad produktami japońskiej kultury popularnej należy także dodać, iż fakt, że zachodni badacze częstokroć nie rozumieli specyfiki japońskiego kontekstu kulturowego i mieli wątłą wiedzę

${ }^{13}$ J. Zaremba-Penk, Japońska popkultura narzędziem podboju świata, [w:] Japoński soft power. Wpływy Japonii na kulturę zachodnią, red. A. Wosińska, Toruń 2010, s. 203-216.

14 A. Allison, The Attractions of the J-Wave for American Youth, [w:] Soft Power Superpowers. Cultural and National Aspect of the Japanese and the United States, red. Y. Watanabe, D.L. McConnell, M.E. Sharpe, New York 2008, s. 99-110; R. Kelts, Japanamerica. How Japanese Pop Culture Has Invaded the U.S., New York 2006.

${ }_{15}$ S. Kinsella, Cuties in Japan, [w:] Women Consumption in Japan, ed. B. Moeran, L. Scov, London 1995, s. 220.

${ }^{16}$ J. E. Ingulsrud, K. Allen, Reading Japan Cool. Patterns of Manga Literacy and Discourse, Plymouth 2009, s. 5.

17 A. Wosińska, Czy zainteresowanie manga i anime wplywa na stan wiedzy o Japonii i poglady na jej temat, [w:] Japoński soft power...., op. cit., s. 217-234.

18 F.L. Schodt, Manga! Manga! The Word of Japanese Comics, Tokyo 1986, s. $153-154$. 
na jego temat, prowadził do formułowania radykalnych wniosków, jakoby kultura japońska była niezwykle brutalna i pozbawiona wartości ${ }^{19}$.

Zgoła odmienne jest stanowisko japońskich badaczy, zdaniem których eksport produktów japońskiej popkultury na Zachód ociepla stosunek do Japończyków wśród pokoleń pamiętających o ich zbrodniach wojennych ${ }^{20}$. Kiyoyuki Kosaka stwierdza nawet, że manga, jako zjawisko niejednorodne, posiadające dużą rozpiętość tematyczną oraz wysoki poziom fabularny i artystyczny, może stanowić atrakcyjny produkt dla każdej płci, grupy społecznej i różnych pokoleń ${ }^{21}$.

\section{PROBLEMY BADAWCZE}

W kontekście niniejszych rozważań wskazać należy, iż w przypadku analizowania kultur oddalonych geograficznie i ideowo od własnej narażamy się na zarzut nadinterpretacji. I choć, jak wskazuje Claude Lévi-Strauss w poświęconej Japonii książce Druga strona księżyca, badacz zachodni napotyka na wiele trudności podczas poznawania kultury odległej od własnej, to zadaniem antropologa jest właśnie badanie takich kultur, co każdorazowo łączy się z ryzykiem niepełnego zrozumienia wielu ich elementów ${ }^{22}$. Krzysztof Loska natomiast stwierdza, że antropolog badający odmienny kontekst kulturowy może odkrywczo ujmować każdy napotykany element, nie rezygnując jednocześnie z rodzimej perspektywy badawczej. Film z kolei winien być badany zarówno jako praktyka społeczna, jak i tekst kultury, będący nie tylko odzwierciedleniem zachodzących przemian obyczajowych, ale również narzędziem kształtowania zbiorowych wyobrażeń. W ten sposób wypracować można szerszą perspektywę badawczą, wzbogaconą o kontekst

19 P. Gravett, Manga. Sixty Years of Japanese Comics, London 2004, s. 9.

20 K. Iwabuchi, Recentering Globalization. Popular Culture and Japanese Transnationalism, Durham 2002, s. 1.

${ }^{21}$ K. Kosaka, Manga a kultura japońska, tłum. M. Taniguchi, A. Watanuki, [w:] Świat z papieru i stali. Okruchy Japonii, red. M. Taniguchi, A. Watanuki, Warszawa 2011, s. 155-160.

22 C. Lévi-Strauss, Druga strona księżyca. Pisma o Japonii, tłum. M. Falski, Kraków 2013, s. 12-13. 
historyczny ${ }^{23}$. Przychodzi więc stwierdzić, iż wszelkie próby interpretacji, zwłaszcza w przypadku audiowizualnych tekstów kultury, sprowadzać będą badacza do roli semiotycznego detektywa, który każdy element wiązać będzie z kolejnym, by ostatecznie dotrzeć do szerokiego kontekstu danej kultury jako całości.

Także $\mathrm{w}$ przypadku tematu podejmowanego $\mathrm{w}$ niniejszym artykule badacz winien posiadać odpowiednie kompetencje interpretacyjne. Musi między innymi znać chociaż w niewielkim stopniu język, by wychwycić gry słów, niezwykle istotne dla japońskich animacji. Po wtóre, musi być świadom tego, jak na przestrzeni dekad zmieniała się sama popkultura, co wynikało z szerszych przekształceń struktury społecznej Japonii oraz rosnącej amerykanizacji kultury. Kolejnym czynnikiem, który badacz musi uwzględnić, jest świadomość specyfiki gatunku, jakim jest japońska animacja, a także jej hybrydycznej natury, co związane jest z szerszym zjawiskiem kryzysu gatunków filmowych. Ostatnim, a zarazem najważniejszym elementem winno być posiadanie wiedzy o szerokim kontekście historyczno-mitologicznym, co pozwala na odróżnienie czynników wywodzących się z kultury japońskiej od tych, które są twórczą (bądź odtwórczą) realizacją wzorców zaczerpniętych skądinąd. Obowiązkiem widza-badacza-detektywa jest bowiem poprawna identyfikacja postaci, sceny, muzyki, wydarzenia itd., i odniesienie ich do właściwego kontekstu. Dopiero posiadanie powyższego zestawu kompetencji daje możliwość prawomocnego analizowania japońskiego anime oraz klasyfikowania jego gatunków lub poszczególnych serii jako kiczu.

Problemy przy analizowaniu zagadnień estetyki japońskiej mają również charakter językowy. Pewne mocno zakorzenione w japońskim kontekście kulturowym określenia, jak na przykład: shibui, yuugen, mono no aware, wabi sabi, nie dają się przełożyć na języki zachodnie, co wynika przede wszystkim z ich silnych konotacji etycznych. Obecny w kulturze japońskiej splot estetyki i etyki można odnaleźć w każdej praktycznie czynności: jedzeniu, oglądaniu drzewa wiśni, hodowaniu drzewka bonsai, umieraniu. Jednocześnie hierarchizacja i dążenie do doskonałości sprawiły, iż produkty słabsze, gorszej jakości, nie były wprowadzane do obiegu społecznego,

23 Traumy japońskiego kina (wywiad Jakuba Przybyło z Krzysztofem Loską), http://ekrany.hekko24.pl/images/teksty/15/15_film\%20wspolczesny_wywiad\%20 Loska.pdf [data dostępu: 22.03.16]. 
dlatego też kicz analogiczny do tego, jaki Hendrykowski odnajdywał w minionych wiekach kultury europejskiej, w Japonii nie mógł zaistnieć. Byłby bowiem sprzeczny nie tylko $\mathrm{z}$ estetyką, ale i z etyką ${ }^{24}$.

Animacje japońskie, choć są wytworem, którego proweniencję łączyć należy z drzeworytem japońskim, stanowią hybrydę wzorców rodzimych $\mathrm{z}$ amerykańskimi. Dlatego też ich analiza za pomocą zachodniej nomenklatury - w tym między innymi pojęć kiczu i kampu - wydaje się uprawniona. Należy przy tym również zauważyć, że zjawisko kiczu w japońskiej animacji jest bezpośrednio powiązane $\mathrm{z}$ charakterystyczną dla kultury masowej komercją.

\section{ANIME - CZĘŚCI SKŁADOWE, ZWIĄZKI Z KOMERCJĄ}

Animacje japońskie, jako produkty kultury popularnej, nie są autonomiczne. Ich pojawienie się w telewizji czy w Internecie łączy się bezpośrednio ze sprzedażą mang. Jeśli dana historia jest popularna jako komiks i plasuje się wysoko w rankingach czytelniczych, studio decyduje się na wykupienie praw i stworzenie serii animowanej. Na tym jednak proces realizacyjny się nie kończy. Jeśli twórcy chcą dobrze sprzedać daną serię, zatrudniają najbardziej znanych seiyuu ${ }^{25}$, angażują popularny zespół do wykonania opening i ending ${ }^{26}$, nadzór nad całością natomiast powierzają jakiemuś cenionemu reżyserowi. Dodatkowo aktywuje się cała branża przemysłu „gadżeciarskiego", który produkuje dla fanów figurki, torby, poduszki, plakaty itd. Dlatego też na rynku dostępna jest szeroka gama artykułów związanych

${ }^{24}$ A. Wierzbicka, Słowa klucze. Różne języki - różne kultury, tłum. I. Duraj-Nowosielska, Warszawa 2007; Estetyka Japońska. Antologia, t. 1: Wymiary przestrzeni, red. K. Wilkoszewska, Kraków 2001; C. Sartwell, Six Names of Beauty, New York 2006.

${ }^{25}$ Seiyuu - aktor głosowy. Najbardziej znani są także aktorami, muzykami, postaciami szeroko rozpoznawalnymi, kreowanymi często na idoli.

${ }_{26}$ Opening i ending - muzyczne sekwencje rozpoczynające i kończące odcinek, wykonywane najczęściej przez dwa różne, popularne w danym czasie zespoły. Mogą to być piosenki adaptowane $\mathrm{z}$ (najnowszej) płyty zespołu lub napisane specjalnie na potrzeby danego anime. W niektórych przypadkach opening lub ending śpiewane są przez głównego seiyuu serii. 
z anime - od produktów codziennych (ubrania, sztućce, zastawa itd.), przez sprzęt, po przedmioty i treści o charakterze pornograficznym.

Anime staje się w ten sposób produktem dla subkultury, adresowanym do tak zwanych otaku ${ }^{27}$, i bardzo często zatraca swą wartość artystyczną wskutek nacisku na aspekt komercyjny. Proces ten związany jest także ze współczesną hybrydyzacją gatunków, która wynika z postulatu, by każdy widz odnalazł w danej serii coś, co wzbudzi jego zainteresowanie. I tak na przykład serie shounen ${ }^{28}$, po dziś dzień jedne $\mathrm{z}$ najbardziej popularnych, tracą swoją autonomiczność na rzecz wątków, które mają im zaskarbić większą oglądalność.

Najbardziej komercyjne wydają się serie aspirujące do bycia shounen, podczas gdy ich schematy oraz wątki fabularne wskazują na to, iż są to raczej tak zwane ecchi ${ }^{29}$. Forma jest więc następująca: chłopiec (najczęściej otaku) uczęszczający do liceum, niepopularny wśród rówieśniczek, zyskuje moce ponadnaturalne (często od bóstwa wywodzącego się z mitologii), w efekcie czego przenosi się do innego świata, gdzie jego życie zupełnie się zmienia otaczają go tam przede wszystkim kobiety, najczęściej nastolatki (harem), z których każda posiada atrybuty uznawane $\mathrm{w}$ Japonii za fetysze ${ }^{30} \mathrm{i}$ jest

27 Otaku - osoba uzależniona od produktów popkultury japońskiej. W Japonii zjawisko to uznawane jest za negatywne, a otaku uważa się często za osoby chore, mające problem $\mathrm{z}$ nawiązywaniem kontaktów z rówieśnikami, żyjące $\mathrm{w}$ świecie ułudy.

${ }_{28}$ Shounen (jap. 'chłopiec') - serie dla chłopców opierające się na męskich protagonistach. Głównymi elementami fabularnymi są walki, podczas których postaci wykrzykują nazwy ataków. Serie te wywodzą się z kultury samurajskiej, w której wojownicy także w czasie walki informowali swojego przeciwnika o wykonywanej technice (będącej najczęściej tajemnicą danego klanu). Jeszcze w latach 80. XX wieku główny protagonista był mężczyzną w wieku 20-25 lat, dziś, w wyniku zauważalnego zinfantylizowania japońskiej animacji, główny bohater jest nastolatkiem.

${ }^{29}$ Ecchi (jap. 'zboczeniec') - animacje, w których celowo stosuje się tak zwany fanserwis (elementy niebędące niezbędnym składnikiem animacji, mające jedynie na celu spełnienie życzeń fanów), a wszelkie wątki, w tym sceny walki, służą jedynie eksponowaniu nagości; przykładem może być Dog Days z 2010 r.

30 Temat fetyszy w japońskiej animacji jest niezwykle rozwinięty, a zarazem skomplikowany. Łączy się bowiem z faktem, iż postaci z popkultury od dekad 
nim seksualnie zainteresowana. Ponadto wywodzące się z walk samurajów krwawe pojedynki sprowadzają się do takiego posługiwania się bronią przez głównego bohatera, by udało mu się usunąć ubrania ze swoich przeciwniczek - późniejszych towarzyszek. Inne postaci męskie pojawiają się jedynie epizodycznie i nie są istotne dla historii. W kwestii samej fabuły zauważyć należy, iż występuje ona jedynie szczątkowo, w ogólnym zarysie, i nie dąży do ostatecznego rozwiązania. Nie występują też nagłe zwroty akcji.

Bohaterowie w seriach ecchi nie doświadczają przemian psychofizycznych, wydają się jednakowi od początku do końca danej produkcji, i jest to ewidentnie przypadłość współczesnej animacji japońskiej. Jeszcze w latach 80. i 90. XX wieku w seriach takich jak np. Hokuto no Ken widz śledził przede wszystkim rozwój postaci, co pozwalało mu na identyfikowanie się z bohaterami (proces projekcji identyfikacyjnej) i przeżywanie wraz z nim wszelkich wydarzeń i wyborów. Adwersarze - niegdyś postaci niejednoznaczne ${ }^{31}$, które bohater spotykał na swojej ścieżce w wyniku zawiłego splotu akcji - dziś zupełnie zatracili swoją funkcję. We wspomnianych seriach ecchi mogą nie pojawiać się wcale lub też funkcjonują jako quasi-antagoniści, którzy nie stanowią realnego zagrożenia dla żadnej z postaci. Jaka jest więc ich rola, skoro dawne serie shounen opierały się na wzajemnych animozjach dwóch przeciwstawnych sił? Przede wszystkim ecchi nie ma stanowić rozrywki intelektualnej, zatem motywacje bohaterów schodzą na ostatni plan. Ponadto, protagonista jest obecnie także komediantem, więc i jego rola jako wybawiciela zostaje spłycona.

Kolejnym elementem charakterystycznym dla wspomnianego gatunku jest tak zwana kreska, czyli sposób rysowania bohaterów, tła itd. Fizjonomia postaci z mang i anime jest efektem fascynacji Osamu Tezuki, ojca japońskiej animacji, popkulturą amerykańską (zwłaszcza Silly Symphonies, Merry

przenikają do sfery pornografii (hentai). Z racji tego, że jedynie od twórcy zależy fizjonomia postaci, wprowadza się wiele różnych typów kobiet różniących się kolorem i długością włosów, uczesaniem (popularne są zwłaszcza kucyki), wielkością biustu, strojem (największym powodzeniem cieszą się mundurki, stroje kąpielowe i bikini). Nawet okulary uważane są za fetysz, jeśli nosi je odpowiednia postać.

${ }_{31}$ Na przykład Raoh z mangi/anime Hokuto no Ken czy Nakago z mangi/anime Fushigi Yuugi. 
Melodies i Waltem Disneyem ${ }^{32}$ ) i została na trwale ustalona, przyjmując formę wręcz kanoniczną. Jednakże o ile jeszcze do niedawna każdy twórca starał się nieco przekształcać ów kanon, by świat przez niego przedstawiony i jego bohaterowie stanowili pewien produkt autonomiczny, współczesne serie ecchi wyglądają, jakby były zrealizowane przez jednego autora. Jak zostało wspomniane, postaci kobiece odzwierciedlają japońskie fetysze, dlatego reprezentują różne typy fizjonomiczne. Sprowadzają się jednak do formy odrealnionej, o idealnym, pozornie proporcjonalnym ciele, gładkiej skórze bez niedoskonałości oraz strojach naśladujących japońskie mundurki szkolne, zaprojektowane tak, by podkreślały wszystkie kobiece walory. Przedstawiając sposób poruszania się kobiet, twórcy starają się odzwierciedlać naturalne ruchy, efekt jest jednak sztuczny, a bohaterki zdają się chodzić, jakby nie dotykały podłoża. Mężczyźni, zwłaszcza antagoniści serii, są najczęściej bardzo szczupli, niczym się niewyróżniający ${ }^{33}$, ubrani w zwykły mundurek szkolny, o twarzach najczęściej lekko sfeminizowanych i niepewnych ruchach.

Kolorystykę ecchi cechuje wielobarwność zarówno postaci, strojów, jak i otoczenia. Całość wydaje się przytłaczająca, co wprowadza efekt horror vacui. Monochromatyzm praktycznie się nie pojawia, a widz narażony jest na nadmiar bodźców. Zwłaszcza krajobrazy przedstawione są bardzo szczegółowo, co z pewnością wynika z udogodnienia, jakie wprowadziły techniki komputerowe przy tworzeniu animacji.

Muzyka jedynie dopełnia ów obraz. Wspomniani seiyuu naśladują często głosy dziewczynek o bardzo wysokim tembrze, natomiast protagoniści, z racji tego, że są nastolatkami, także mają podłożone głosy kobiece. Wspomniane muzyczne czołówki (openings) oraz końcówki (endings) nie stoją na wysokim poziomie. Najczęściej śpiewane są przez aktualną japońską idolkę - nastolatkę o wysokim głosie, słowa natomiast nie mają większego znaczenia i są bardzo naiwne w swej wymowie.

${ }^{32}$ Należy tu nadmienić, iż jeszcze przed Tezuką, zwłaszcza w czasie II wojny światowej, pojawiały się nawiązania do wskazanych twórców i serii amerykańskich, jednakże to dopiero Tezuka ujednolicił kanon.

33 Podczas gdy kolor włosów u kobiet reprezentuje całą gamę barw, u mężczyzn odcienie są najczęściej naturalne - czarne, brązowe. 


\section{KICZ CZY KAMP?}

Pozostaje teraz postawić dwa pytania. Po pierwsze, co decyduje o przyjęciu takiej stylistyki? Po drugie, czy można uznać ecchi za przykład kiczu?

Po przedstawionej powyżej charakterystyce serii ecchi obraz japońskiej animacji może wydać się lekko zniekształcony. Serie z dominującą ilością podtekstów seksualnych, choć współcześnie przeważają, nie są jedynymi wydawanymi na rynku komercyjnym. Ich popularność wynika z kilku faktów. Przede wszystkim ich głównymi odbiorcami są samotni chłopcy i mężczyźni, wspomniani otaku, którzy w życiu osobistym mają problem z nawiązywaniem kontaktów z płcią przeciwną. Serie, w których głównym bohaterem jest nieśmiały, samotny mężczyzna, wywołują znaczny oddźwięk społeczny, gdyż pozwalają wspomnianym otaku na proces identyfikacji z bohaterem, który chociaż pozostaje sobą, to spotyka sporą liczbę atrakcyjnych kobiet, z których każda jest nim seksualnie zainteresowana. Ten pozornie naiwny element sprawia, że komercyjne ecchi sprzedają się bardzo dobrze na rynku animacji i nie zagraża im zatrzymanie produkcji. Z uwagi jednak na fakt, iż w obrębie powyższego gatunku panuje duża konkurencja, twórcy decydują się na rozwiązania hybrydyczne pod względem gatunkowym. Wprowadzają zmiany w obrębie struktury, dodając wiele nowych elementów, np. bogów, anioły, demony, roboty, postaci zoomorficzne, mityczne i fantastyczne krainy itp. Ma to na celu zainteresowanie widza o każdych preferencjach, w tym także amatorów wspomnianych fetyszy. Taką samą funkcję pełni kolorystyka, która winna się rzucać w oczy, i choć sprawiać może ona wrażenie cukierkowej i dziecinnej, widz - poprzez wspomniany fanserwis - od razu otrzymuje sygnał, iż ma do czynienia z serią ecchi. Ponadto seiyuu to najczęściej atrakcyjne kobiety, japońskie celebrytki obecne w wielu mediach, kreujące się w określony sposób i pełniące funkcje idolek, spotykające się z fanami na zlotach i wydarzeniach popkulturowych.

W związku z powyższymi uwagami zastanowić się należy, czy serie ecchi są kiczem, czy też bliżej im do kampu? A zatem - czy mamy do czynienia ze świadomym przerysowaniem pewnych elementów, gloryfikacją sztuczności, ironią, czy też z zaburzeniem przyjętego kanonu estetycznego i niską jakością produktów?

Cechą wspólną kampu oraz serii ecchi jest z pewnością wspomniane przerysowanie. Jednakże w japońskich animacjach nie pełni ono funkcji ironicznych, nie służy naśmiewaniu się z obowiązujących konwencji. Jest 
celowym zabiegiem marketingowym, który pozwala na przyciągnięcie większej liczby różnorodnych widzów do jednego anime, co w rezultacie prowadzi do produkcji szeregu gadżetów. Także sztuczność jest gloryfikowana, jednak w innym celu, niż ma to miejsce w realizacjach kampowych. Wiąże się ona bowiem z utrwalonym kanonem, który wyznacza genezę subkultury otaku i wspomnianych już fetyszy. Dlatego też należy jednoznacznie odrzucić tezę, iż anime z serii ecchi są produktami kampowymi. Jak wykazaliśmy powyżej - nie wpisują się one w ramy przynależne tej kategorii.

Czy zatem są kiczem? Z pewnością tak, jednak tylko z perspektywy widza reprezentującego zachodni kontekst kulturowy. Pamiętać przy tym należy, że ecchi stanowi jedynie wycinek zjawiska, jakim jest anime, i nie powinno wpływać na opinię o całości. Tym bardziej że wciąż powstaje wiele animacji, które można określić jako dzieła sztuki, animacji, w których estetyka i etyka japońska stanowią podstawę zarówno formy, jak i treści ${ }^{34}$.

Niemniej jednak, odnosząc się do naszego macierzystego kontekstu kulturowego, serie ecchi zakwalifikować należy jako kicz. Nie prezentują one większych wartości artystycznych, wartość poznawcza nie stoi tu na wysokim poziomie (w przeciwieństwie do innych gatunków), barwność, „cukierkowość” i naiwność infantylizują przekaz, natomiast spłycenie wątków fabularnych i charakterów postaci równoważne jest z pozbawieniem fabuły jakichkolwiek zwrotów akcji i zaskoczeń. Ostatecznie jednak, jako produkty kultury masowej, produkcje te stają się - zgodnie z określeniem Abrahama Molesa - „sztuką szczęścia” dla swoich odbiorców.

\section{ESTETYKA JAPOŃSKA I SERIE ECCHI}

Trudniejsze jest natomiast wskazanie, czy te same czynniki mogą decydować o zaklasyfikowaniu jakiegoś elementu jako kiczu w wewnętrznym kontekście japońskiego kręgu kulturowego. W tym celu spróbujemy porzucić na chwile nasze zachodnie schematy myślowe, a jako prymarne kategorie przyjąć japońskie wartości estetyczne. Jak pisze Krystyna Wilkoszewska:

[...] piękno w naszej europejskiej tradycji osiągnęło wymiar transcendentalny i absolutny zarazem, co znaczy, że było pojmowane jako niezmienne, wieczne i bezwzględne. Jego ziemskie odbicie zyskiwało swój możliwie

${ }^{34}$ Np. manga i anime Hunter X Hunter autorstwa Togashi Yoshihiro. 
najdoskonalszy kształt na podstawie takich cech przedmiotu, jak symetria, proporcja i dopełnienie, dających w rezultacie harmonijną jedność w wielości ${ }^{35}$.

Jednakże estetyka japońska nie jest tożsama z zachodnią, dlatego zarówno pojęcia, jak i ramy interpretacyjne są tu zupełnie inne. I tak też nie będziemy od tej chwili odwoływać się do wrażliwości Europejczyka, natomiast spróbujemy przyjąć perspektywę uczestnika japońskiego kręgu kulturowego.

Pierwszą wartością charakterystyczną dla wschodniego myślenia o sztuce będzie bliskość człowieka z naturą. Większość badaczy uważa, że to właśnie ten czynnik szczególnie odróżnia nasze pojęcie estetyki od japońskiego ${ }^{36}$. Dążenie do osiągnięcia harmonii między człowiekiem i naturą przekłada się tutaj na osiągnięcie harmonii między wytworem ludzkim a jego naturalnym otoczeniem. Należy zauważyć, że istota ludzka ma w Japonii taką samą wartość jak natura. Uwidacznia się tu zasadnicza różnica pomiędzy zachodnim antropocentryzmem a perspektywą japońską, która uznaje człowieka za część przyrody - nie jest on od niej ani lepszy, ani mądrzejszy, stanowi taki sam element jak woda czy zwierzę ${ }^{37}$.

Może się wydawać, iż takie ujęcie tym mocniej każe dostrzegać w ecchi produkt japońskiego kiczu, jednakże nawet w tych seriach - mimo iż jakość ich wykonania i struktura fabularna nie nadają im rangi dzieł sztuki - równowaga ta jest zauważalna. Także tu bowiem widoczna jest fuzja etyki z estetyką. Dużo uwagi poświęca się w nich krajobrazom, a człowiek i zwierzę stoją na tym samym poziomie hierarchii, czasem nawet tworząc hybrydy ${ }^{38}$. Z kolei pojawiające się światy fantastyczne to najczęściej transpozycja japońskiego porządku w inne ramy, przy czym sama struktura pozostaje niezmienna.

Kolejnymi obecnymi w popkulturze cechami estetyki japońskiej są nietrwałość i ulotność, związane - na przykład w sztuce drzeworytniczej lub poezji - w sposób jednoznaczny z naturą, a szczególnie z uwrażliwieniem

${ }^{35}$ K. Wilkoszewska, Estetyka japońska. Wprowadzenie, [w:] Estetyka japońska..., op. cit., s. 7.

${ }^{36}$ P. Mason, History of Japanese Art, New York 1993

37 K. Wilkoszewska, op. cit., s. 30.

38 Popularne są zwłaszcza kobiety z kocimi uszami, co uważa się za kawaii, czyli 'słodkie'. 
na pory roku. Cechy te dostrzec można między innymi w praktyce obserwowania kwitnących drzew wiśni, ale także w architekturze, gdzie w przeciwieństwie do zachodnich wzorców - nawet jeśli budowla posiada wysoką wartość artystyczną, to z przyczyn użytkowych już kilka dekad po powstaniu jest wyburzana i wznoszona na nowo przy użyciu nowych materiałów. Praktyka ta wynika również z położenia geograficznego Japonii, która wielokrotnie w historii narażona była na zniszczenia wywołane atakami tsunami czy trzęsieniami ziemi. Ulotność stała się więc koniecznym elementem zarówno etyki, jak i estetyki.

Rys nietrwałości odnajdujemy także w seriach ecchi, gdzie łączy się on bezpośrednio z aspektem komercyjnym. Dążenia do zaspokojenia zmiennych zainteresowań widza skutkują bowiem przekształceniami w obrębie samych serii i ciągłym wprowadzaniem nowych elementów, czego efektem jest swoiste przeładowanie struktury. Należy dodać, iż jest to cecha anime jako całości, gdyż wspomniane komercyjne dążenie do wypracowywania nowych środków sprawia, że choć kanon ukazywania postaci jest utrwalony, wciąż zmieniają się jego części składowe, co z kolei prowadzi do wspomnianego kryzysu gatunków.

Jeszcze inną cechą estetyki japońskiej jest asymetria. W naszej kulturze, miłującej harmonię, zdaje się to trudne do pomyślenia. Tymczasem japońska estetyka świadomie odrzuca symetrię, stosując między innymi nieparzystą liczbę kwiatów w ikebanie, nieparzystą liczbę kamieni w ogrodzie zen czy też nieparzystą liczbę sylab w tradycyjnej poezji $w a k a^{39}$. Asymetria objawia się na kilku płaszczyznach. Może mieć charakter wizualny, co dostrzegalne jest już w najstarszych animacjach, gdzie kluczowe wydarzenia akcji częstokroć przedstawiane są nie w centrum obrazu, a nieznacznie $z$ lewej lub z prawej strony. Często spotyka się również - mimo wprowadzenia, jako dominującej, kompozycji centralnej - umieszczenie jakiegoś istotnego elementu w jednym $z$ rogów ekranu, przez co widz dokonać musi wyboru i skupić wzrok na jednym z tych dwóch punktów. Asymetria występuje także na polu fabularnym - błędne byłoby przekonanie, że każdy odcinek lub seria danej historii jest formą uporządkowaną, w której wszystkie wątki zajmują tyle samo miejsca. W większości przypadków, nawet w krótkich seriach,

${ }^{39}$ K. Wilkoszewska, op. cit., s. 35. 
następuje tu rozbieżność - choć widz śledzi główną akcję i wydaje mu się, że ma ona wartość prymarną, to w drodze do rozwiązania fabularnego następuje seria dygresji zaburzająca porządek narracji. Częstokroć asymetria taka nie jest jednak zamierzona, a wynika między innymi z potrzeby wprowadzenia dodatkowego odcinka, kiedy istnieje ryzyko, że anime za bardzo zbliży się fabularnie do wychodzącej na bieżąco mangi będącej jego źródłem. Czasem też twórcy muszą zmienić tok narracji ze względu na spadki serii w sondażach oglądalności.

Ze świadomym odrzuceniem symetrii wiąże się jeszcze inna wartość estetyki japońskiej, jaką jest fragmentaryczność. To nie całość czy jedność wyznacza w Japonii standardy estetyczne, ale raczej epizodyczność, krótkość formy. Szczególnie ciekawie przedstawia się ta kwestia w malarstwie ${ }^{40}$, choć wiąże się też z prozaicznymi czynnościami. Japończyk, patrząc w określone miejsce, dokonuje „wycięcia” i skupia się jedynie na fragmencie, eliminując z pola widzenia to, co zakłóca ogląd. Nawet u Utagawy Kuniyoshiego, zajmującego się przede wszystkim przedstawianiem na drzeworytach wojowników, na pierwszym planie uwidacznia się jakiś drobny element. Może to być drzewo, ale równie dobrze fragment zbroi samuraja.

Fragmentaryczność można odnieść też bezpośrednio do mang, gdyż w Japonii najpierw publikuje się ich rozdziały czy fragmenty na łamach czasopism i dopiero po opublikowaniu wszystkich części zapada decyzja, czy warto wydać daną mangę w wersji książkowej, czy też lepiej pozostawić ją jedynie jako dzieło epizodyczne, bez jednoznacznego początku i końca. Podobnie w przypadku anime - nawet jeśli mamy do czynienia z serią oznaczoną jako skończona, może to równie dobrze oznaczać, że została ona przerwana ze względu na połączenie się fabuły z serii i mangi, albo też to, że produkcja przestała być popularna. W efekcie w wielu przypadkach nie dochodzi do zwieńczenia fabuły, a problem, z którym mierzyli się bohaterowie, pozostaje nierozwiązany.

Wspomnieć należy także o stosowanej kolorystyce, którą charakteryzują dysonansowe zestawienia, mnogość intensywnych barw, horror vacui. Elementy te są, zwłaszcza w seriach ecchi, zabiegiem komercyjnym, mającym na celu przykucie uwagi widza do pokazywanego obrazu, jednakże

40 Ibidem, s. 37 
praktyki takie stosowane były już w klasycznym drzeworycie japońskim, m.in. u wspomnianego Utagawy Kuniyoshiego. Z uwagi na fakt, iż grafiki wystawiane były w przydrożnych sklepach i wykładano je w kilku poziomach, praktycznie zakrywając powierzchnię targową, twórca, by sprzedać swój produkt, musiał tak zaprojektować kompozycję i jej elementy składowe, żeby przechodzień zwrócił uwagę na daną grafikę i ją zakupił. Także przedstawiona forma uzależniona była (podobnie jak ma to miejsce obecnie) od mody. Dlatego też sama tematyka zmieniała się dość często, tworzono nawet tematyczne hybrydy, łączące aspekty codzienności, teatru, historii i mitologii ${ }^{41}$.

${ }^{41}$ W kontekście estetyczno-etycznym wspomnieć należy również o zależności na linii kobiety - mężczyźni. Jest to bowiem główna oś narracji opisywanych $\mathrm{w}$ anime, a niezwykle popularnym motywem jest tu zamiana ról, np. przebieranie się mężczyzn za kobiety czy przejmowanie przez kobiety typowo męskiej roli uwodziciela. Ukazywanie kobiet w japońskiej popkulturze skupia się obecnie na ich sile fizycznej, znajomości technik walki wręcz i posługiwania się bronią. Bohaterki mają bowiem rekompensować słaby charakter protagonisty. W rzeczywistości jest to jednak motyw uwarunkowany historycznie, odwołujący się do tak zwanych onna-bugeisha, czyli kobiet wojowniczek z klasy samurajskiej, posługujących się, w przeciwieństwie do mężczyzn, nie kataną, a naginatą (zob. E. Amdur, Women Warriors of Japan: The Role of Arms-Bearing Women in Japanese History, www.koryu.com/library/wwj1.html [data dostępu: 13.03.16]). Mężczyźni natomiast, jak ma to miejsce np. w serii Himegoto, przebierani są za kobiety w tzw. stylu kawaii, gdyż w przeciwieństwie do silnych antagonistek, są oni słabi i zniewieściali (także pod względem fizycznym). Przybranie przez nich kobiecego mundurka szkolnego wywołuje u widza wizualny dysonans - stereotypowa kobiecość zamienia się tu bowiem miejscami z męskością. Także i ten zabieg nie jest jednak wytworem współczesnej kultury, gdyż pojawił się dużo wcześniej w przekazach historyczno-mitologicznych. W kulturze japońskiej często pisze się bowiem o męskim pięknie, a nawet najbardziej sławni wojownicy, np. Minamoto Yoshitsune, przebierali się za kobiety w ramach politycznych intryg (zob. S. Turnbull, The Samurai. A Military History, New York 1977). Istotnym jest także fakt, że od pewnego momentu w japońskim teatrze kabuki, realizowanym dla niższych warstw społecznych, role kobiet grali mężczyźni, którym w celu zwiększenia popularności widowisk nakazywano przywdziewanie na co dzień kobiecych strojów i spacerowanie w nich po ulicach miast. Dodać należy także, iż homoseksualizm nie był nigdy dla Japończyków 
Wskazane kategorie estetyczne nie pozwalają zatem uznać ecchi za produkty kiczowate, gdyż wpisują się one w ogólne ramy japońskiego sposobu myślenia. W zasadzie anime, ujęte jako całość, odrzuca jedynie dwie cechy estetyki japońskiej: prostotę oraz oszczędność środków wyrazu ${ }^{42}$, wprowadzając na ich miejsce wartości zaczerpnięte z kultury masowej, co związane jest z zainteresowaniem produktami amerykańskimi w latach 30. XX wieku oraz podczas powojennej okupacji, której konsekwencją była przymusowa transformacja społeczno-kulturowa.

Ostatnią kategorią - także przefiltrowaną przez zachodni kontekst kulturowy - jest estetyczna polaryzacja, czyli współbrzmienie dwóch różnych wrażliwości estetycznych. Pierwsza z nich związana jest z wymienioną już prostotą, druga natomiast odnosi się do przepychu i bogactwa ekspresji artystycznej. Nie jest to jednak również tendencja współczesna, gdyż obie te cechy można odnaleźć już w zabytkach prehistorycznych, następnie $\mathrm{w}$ dawnym malarstwie, literaturze czy architekturze. Wydaje się bowiem, że owa polaryzacja wynika ze współobecności różnych cech japońskiej estetyki: $z$ jednej strony tych, które jawią się jako rdzennie japońskie, trwałe, wywodzące się z kultury arystokracji dworskiej, z drugiej - tych, które zostały przyjęte z kontynentu i zasymilowane bądź też są owocem japońskich gustów plebejskich, częściowo już przemijających ${ }^{43}$.

Dziś owa polaryzacja zauważalna jest w kulturze popularnej, jednak jej źródłem są nie tylko komercyjne potrzeby, ale i tradycyjna japońska estetyka. O ile bowiem sam sposób wykonania, przekazywane treści i wartości uznać można za rdzennie japońskie, o tyle dobór środków wynika już z zapotrzebowania społecznego na dane produkty kultury masowej.

Czy więc serie ecchi także w obrębie japońskiego kontekstu kulturowego będą realizacjami kiczowatymi? Paradoksalnie - nie, gdyż pomimo ich

tematem tabu. Akceptowany był wśród buddystów, samurajów, klasy średniej i arystokracji. Przyjętym było także powszechnie, że mężczyźni naśladujący gejsze lub prostytutki nie tylko odtwarzali ich wygląd, ale także całą sferę zachowań, gestów, rytuałów (zob. G.M. Pflugfelder. Cartographies of Desire: Male-Male Sexuality in Japanese Discourse 1600-1950, http://www.h-net.org/reviews/showrev.php?id=4126 [data dostępu: 13.03.16]).

${ }^{42}$ K. Wilkoszewska, op. cit., s. 37.

43 Ibidem, s. 40. 
formy, barwności, prowadzenia wątków fabularnych w sposób prosty i jednostajny oraz stosowania komercyjnych rozwiązań w celu zainteresowania widzów, wpisują się w one w ramy estetyki japońskiej.

Czy zatem w ogóle możliwe jest zakwalifikowanie jakiegoś elementu lub produktu kultury japońskiej jako kiczu, skoro - jak zostało wspomniane na początku niniejszego wywodu - pojęcie to z przyczyn estetyczno-etycznych nie występuje w tej kulturze? Otóż tak, ale na zupełnie innych zasadach, niż zwykliśmy to czynić. Dawniej bowiem, przed epoką Meiji, hierarchizacja struktury społeczeństwa japońskiego była znacznie bardziej wyraźna i każda jednostka posiadała w jej ramach ściśle wyznaczoną pozycję. Dlatego też produkcja przedmiotów codziennego użytku, kaligrafia czy dzieła rzemieślnicze, do których zaliczylibyśmy też parawany i drzeworyty, były ściśle kontrolowane przez system nadzorców rzemieślników ${ }^{44}$. Żaden produkt, który nie zyskał aprobaty „przełożonego”, nie wchodził do obiegu. Stąd też niełatwo było wypracować sobie status mistrza w danej dziedzinie. Dziś natomiast ów porządek przetrwał szczątkowo, pozostało jedynie kilku mistrzów reprezentujących najwyższy stopień wykonawstwa, których wiedza stanowi tradycję pokoleniową danej szkoły. W miejsce czeladników pojawili się natomiast quasi-artyści. Nie są oni uczniami owych mistrzów, a sztukę tworzenia określonych przedmiotów opanowali na przykład na kursie, w związku z czym ich realizacje nie mogą być porównywane z tymi, które wykonywali mistrzowie. Dlatego też za cnotę uznaje się umiejętność rozpoznawania tego, co jest dziełem mistrza, w odróżnieniu od produktu podrobionego, który jedynie naśladuje oryginał. W efektach pracy mistrza tkwią bowiem wspomniane wartości estetyczne i etyczne, podczas gdy produkty quasi-artystów ich nie posiadają i mogą co najwyżej udawać pierwowzór. Funkcjonowanie quasi-artystów wynika także $\mathrm{z}$ warunków komercyjnych, gdyż na ich dzieła istnieje zapotrzebowanie wśród mas, które nie oczekują od kupowanych towarów, iż będą im dostarczać wyrafinowanych uniesień. Odbiorcą jest więc klient masowy, który nie dostrzega różnicy między dziełem mistrza a „uzurpatora”. Co jednak istotne, nie wychwytują jej też badacze wywodzący się z innego kontekstu kulturowego. Mogą oni, na

44 Potem, w epoce Shōwa, sytuacja wygląda podobnie przy realizacji pierwszych kinematograficznych dzieł japońskich; zob. K. Loska, Nowy film japoński, Kraków 2013. 
przykład w przypadku ikebany, polegać na takim ułożeniu kwiatów, które Europejczyk uzna za piękne, chociaż dla Japończyka o wysokich kompetencjach kulturowych stanowić będzie ono poważne naruszenie przyjętych zasad.

Ecchi będzie zatem produktem kiczowatym tylko dla odbiorcy zachodniego, operującego innymi kryteriami estetycznymi. Tak też zachodni badacz z łatwością uznać może serie ecchi za kicz - przykład opisanej przez Adorno parodii katharsis, rodzaj fałszywej świadomości, iluzję pomagającą ludziom zaakceptować niesprawiedliwy porządek społeczny ${ }^{45}$. Tym bardziej że analizowane serie realizowane są przecież z myślą o otaku, dla których anime stanowi proces identyfikacyjnej projekcji.

W ujęciu zaś japońskim produkcje anime - będące hybrydą wzorców rodzimych $\mathrm{z}$ amerykańskimi - nie będą wpisywać się $\mathrm{w}$ ramy kiczu i kampu, gdyż ich części składowe przynależą do sfery etyczno-estetycznej głęboko zakorzenionej w świadomości i tradycji wytwórczości japońskiej. I pomimo uzależnienia animacji japońskich od masowych zapotrzebowań wskazać należy, iż elementy komercyjne nakładają się jedynie na strukturę poszczególnych produkcji, nie zmieniając jej rdzenia, który wywodzi się z tradycyjnej estetyki japońskiej.

Powyższe rozważania wykazały więc, iż niewskazane jest zarówno generalizowanie, jak też przyjmowanie tych samych kategorii opisowych dla produktów o różnej proweniencji kulturowej. Badacz winien natomiast posiadać odpowiednią wiedzę oraz zespół cech umożliwiających mu jak najwierniejsze opisanie, zanalizowanie i zinterpretowanie wszystkich zjawisk i kontekstu kulturowo-społecznego zarówno kultury własnej, jak i odległej geograficznie czy ideowo.

\section{Bibliografia}

Adaptacje literatury japońskiej, red. K. Loska, Wydawnictwo UJ, Kraków 2012. Anne Allison, The Attractions of the J-Wave for American Youth, [w:] Soft Power Superpowers. Cultural and National Aspect of the Japanese and the United States, ed. Y. Watanabe, D.L. McConnell, M.E. Sharpe, New York 2008.

${ }^{45}$ A. Leszczyński, Koniec kiczu, http://www.wiz.pl/8,71.html [data dostępu: 13.03.16]. 
Theodor W. Adorno, Sztuka i sztuki. Wybór esejów, tłum. K. Krzemień-Ojak, Wydawnictwo Naukowe PWN, Warszawa 1990.

Andrzej Banach, O kiczu, Wydawnictwo Literackie, Kraków 1968.

Hermann Broch, Kilka uwag o kiczu i inne eseje, tłum. G. Borkowska, J. Garewicz, R. Turczyn, Czytelnik, Warszawa 1998.

Jonathan Clements, Helen McCarthy, The Anime Encyclopedia. A Guide to Japanese Animation Since 1917, Stone Bridge Press, New York 2001.

Dariusz Czaja, Mitologie popularne. Szkice z antropologii współczesności, Universitas, Kraków 1994.

John Fiske, Zrozumieć kulturę popularna, tłum. K. Sawicka, Wydawnictwo UJ, Kraków 2010.

Marian Golka, Socjologia kultury, Wydawnictwo Naukowe „Scholar”, Warszawa 2008.

Paul Gravett, Manga. Sixty Years of Japanese Comics, Harper Design, London 2004. Mirosław Filiciak, Anime, [w:] Wokół kina gatunków, red. K. Loska, Rabid, Kraków 2001.

Marek Hendrykowski, Kłopoty z kiczem filmowym, [w:] Niedyskretny urok kiczu. Problemy filmowej kultury popularnej, red. G. Stachówna, Universitas, Kraków 1997.

John E. Ingulsrud, Kate Allen, Reading Japan Cool. Patterns of Manga Literacy and Discourse, Lexington Books, Plymouth 2009.

Koichi Iwabuchi, Recentering Globalization. Popular Culture and Japanese Transnationalism, Duke University Press, Durham 2002.

Roland Kelts, Japanamerica. How Japanese Pop Culture Has Invaded the U.S., Palgrave Macmillan, New York 2006.

Sharon Kinsella, Cuties In Japan, [w:] Women Consumption in Japan, ed. B. Moeran, L. Scov, Routledge, London 1995.

Antonina Kłoskowska, Kultura masowa, Wydawnictwo Naukowe PWN, Warszawa 2005.

Kiyouki Kosaka, Manga a kultura japońska, tłum. M. Taniguchi, A. Watanuki, [w:] Świat z papieru i stali. Okruchy Japonii, t. 1, red. M. Taniguchi, A. Watanuki, Waneko, Warszawa 2011.

Maria Kozłowska, Tadeusz Korsak, Słownik japońsko-polski, Wiedza Powszechna, Warszawa 2010.

Marek Krajewski, Kultury kultury popularnej, Wydawnictwo Naukowe UAM, Poznań 2003. 
Beata Kubiak Ho-chi, Estetyka i sztuka japońska. Wybrane zagadnienia, Universitas, Kraków 2009.

Agnieszka Lech, Leksykon manga \& anime, Mater, Szczecin 2004.

Claude Lévi-Strauss, Druga strona księżyca. Pisma o Japonii, tłum. M. Falski, Wydawnictwo UJ, Kraków 2013.

Penelope Mason, History of Japanese Art, The Society for Japanese Studies, New York 1993.

Abraham Moles, Kicz, czyli sztuka szczęścia. Studium o psychologii kiczu, tłum. A. Szczepańska, E. Wende, PIW, Warszawa 1978.

Bogusław Nowak, Słownik znaków japońskich, Wiedza Powszechna, Warszawa 2007.

Frederik L. Schodt, Manga! Manga! The Word of Japanese Comics, Kodansha, Tokyo 1986.

Susan Sontag, Notatki o kampie, tłum. M. Wertenstein, „Literatura na Świecie” 1979, nr 9.

Dominic Strinati, Wprowadzenie do kultury popularnej, tłum. W.J. Burszta, Wydawnictwo Zysk i S-ka, Poznań 1998.

Stephen Turnbull, The Samurai, A Military History, MacMillan Publishing Co., New York, 1977.

Anna Wierzbicka, Słowa klucze. Różne języki - różne kultury, Wydawnictwo UW, Warszawa 2007.

Krystyna Wilkoszewska, Eseje o pięknie. Problemy estetyki i teorii sztuki, PWN, Warszawa 1988.

Krystyna Wilkoszewska, Estetyka japońska. Wprowadzenie, [w:] Estetyka japońska, Antologia, t. 2: Słowa i obrazy, Universitas, Kraków 2001.

Adrianna Wosińska, Czy zainteresowanie manga $i$ anime wplywa na stan wiedzy o Japonii i poglady na jej temat, [w:] Japoński soft power. Wplywy Japonii na kulturę zachodnia, red. A. Wosińska, Kirin, Toruń 2010.

Adrianna Wosińska, Inspirujaca i inspirowana popkultura japońska, Kirin, Toruń 2011.

Joanna Zaremba-Penk, Japońska popkultura narzędziem podboju świata, [w:] Japoński soft power. Wpływ Japonii na kulturę zachodnia, red. A. Wosińska, Kirin, Toruń 2010. 


\section{Źródła internetowe}

Ellis Amdur, Women Warriors of Japan: The Role of Arms-Bearing Women in Japanese History, http://www.koryu.com/library/wwjl.html.

Gregory M. Pflugfelder. Cartographies of Desire: Male-Male Sexuality in Japanese Discourse 1600-1950, http://www.h-net.org/reviews/showrev.php?id=4126 Traumy japońskiego kina (wywiad Jakuba Przybyło z Krzysztofem Loską), http:// ekrany.hekko24.pl/images/teksty/15/15_film\%20wspolczesny_wywiad\%20 Loska.pdf.

Adam Leszczyński, Koniec kiczu, http://www.wiz.pl/8,71.html.

\section{Imported Kitsch? Introduction into Reception and Critique of Japanese Animation}

This paper delves into the meaning of kitsch in Japanese popular culture through the analysis of their esthetical and ethical values, as well as historical-religious context. It proves also the difficulties of studying the aforementioned culture because of the geographical remoteness of this country and different mentality of its people. The text shows the beginnings of Japanese animation, called 'anime' for short, its essential parts and the overall canon. The most important aspect of this work is finding the answer whether anime and all its related products are associated with kitsch, camp or should they be interpreted as something completely different.

Keywords: kitsch, camp, Japan, anime, manga, animated movie 